\title{
BALAIADA: AÇÃO E EXPLORAÇÃO.
}

\section{MARIA DE LOURDES MONACO JANOTTI \\ Disciplina: História do Brasil.}

\section{I}

"Ilmo. Sr. Capitão Manuel Alves d'Abreu. Vila da Manga, 15 de dezembro de 1838. Como Acho nesta Vila com a Reunião do Povo e bem do socego publico como consta dos Art. 9 sigTe. 19) Que seja sustentada a constituição e garantido dos cidadãos. 29) Que seja admetido o Presidente de Provincia e em Tregue o governo Vice-Prezidente. $3^{\circ}$ ) Que seja abolidos os Prefeitos e Subs-Prefeitos, Comissarios ficando som.tes em Vigor- as Leis geraes e as Provincias que não forem de em contro a Constituição do Império. $4^{\circ}$ ) Que sejão espulcados empregos portuguezes e Dispejarem A Provinsia dentro em 15 dias com exseção dos cazados com familias brasileiras e os de 60 anos para sima.

Raimundo Gomes Vieira - Comde da Forca armada.

Segeu o Cap. Alberto Gomes Ferreira avizar todos os Cidadoes Brasileiros e amigos da Patria e do sucego Publico para se acharem neste Quartel da forca Armada para o bem do Brazil. Quartel da Forca.

Manga 14 de Dr.o de 1838. Comde da Forca. Fora feitores e escravos.

$$
\text { R. G. V.". }
$$

A 13 de dezembro de 1838, a vila da Manga, no Maranhão, foi invadida por um pequeno grupo de homens, que visava assaltar a cadeia local. Nela estavam detidos há dois dias alguns vaqueiros, seus companheiros de viagem, que habitualmente levavam e traziam gado do Maranhão para o Piauí. Eram todos eles empregados do Pe. Inácio Mendes de Morais e Silva, pessoa influente e temida no sertão do Brejo, tido como membro da oposição ao governo. 
Raimundo Gomes Vieira, capataz do grupo, chefiou o assalto à prisão, e depois de libertar os detidos e conseguir a adesão do destacamento local da guarda-nacional, assenhoriou-se do lugarejo, dando início a um movimento que polarizaria, em torno de si durante dois anos e meio, os acontecimentos históricos do norte do país. Começava a Balaiada. Um manifesto de teor político foi divulgado, com extraordinária rapidez, por toda a Província, expondo as reivindicações do grupo de vaqueiros. A redação do documento foi motivo de diferentes interpretações a respeito de sua autoria. Uns diziam-no propositamente mal redigido, para que assim os verdadeiros autores ficassem acobertados; outros asseveravam que somente a Raimundo Gomes cabia a responsabilidade do seu conteudo, pois os erros gramaticais evidenciavam um autor não acostumado ao manejo da pena.

A Província do Maranhão estava conturbada por acerbas disputas políticas entre bentevís e cabanos, desde a abdicação de D. Pedro I. A renúncia de Feijó aprofundara as divergências no grupo social dominante, acentuando os antigos ressentimentos gerados pela Setembrada de 1831. Naquela ocasião a repulsa à influência dos portugueses e ao absolutismo do monarca congregara um grupo político, que se identificava aos liberais exaltados e que posteriormente, foi várias vezes acusado de esposar idéias republicanas. Os exaltados nunca admitiram publicamente serem adeptos das perigosas doutrinas de Comte, e embora existissem entre eles alguns republicanos, eram em número inexpressivo. Durante o governo de Feijó os liberais, popularmente chamados de bentevís, excerceram completa autoridade sobre a Província, relegando seus antagonistas, os cabanos, ao ostracismo político. Estes, haviam se originado do partido português, que pretendia a volta de D. Pedro I ao Brasil; e em 1838 identificavam-se com a política centralista de Bernardo Pereira de Vasconcelos.

Com a regência de Araujo Lima, a situação no Maranhão inverteu-se, tendo os cabanos ascendido aos postos anteriormente ocupados por seus rivais. Os anos em que permaneceram afastados do poder aumentaram seu ressentimento em relação aos bentevís. Os novos senhores vinham, sequiosos de vingança, ocupar o seu lugar na administração. Compunham a maioria na Assembléia Provincial, fazendo aprovar inúmeros projetos até então sistematicamente rejeitados. Formaram ao lado do Presidente Vicente Pires de Camargo um governo todo poderoso, onde a minoria liberal não chegava nunca a pesar nas decisões.

Repetindo os mesmos processos que os liberais haviam utilizado no governo anterior, agora os cabanos dirigiam as eleições à sua maneira, através da fraude e da violência. Os liberais responsabilizavam o Regente e o Ministério por acobertarem a corrupção que se instaura- 
ra na Província; o Presidente, pela desmoralização da Assembléia e aviltamento da imprensa; os cabanos, pelo desregramento administrativo e malbaratamento do erário público; e a todos esses por estabelecerem no Maranhão um governo que, para atingir seus torpes objetivos, servia-se de "expedientes e transações" (1).

A luta política no Maranhão era a mesma que se dava em nivel nacional, resultante das divergências dentro do estamento dominante, acerca da melhor forma de governar o país. Confundiam os estamentos sociais inferiores, procurando afasta-los dos reais motivos de suas dissidências, com argumentos ideológicos de fundo nacionalista .

Ainda as velhas questões entre brasileiros natos e adotivos eram motivos de desavenças e arruaças. Os partidos radicalizavam-se e a violência armada pelos fazendeiros de algodão era usual. $O$ assassinato do político Raimundo Teixeira Mendes, considerado chefe da oposição, desencadeou virulenta campanha jornalística contra os cabanos no poder. A imprensa maranhense, considerada uma das mais importantes da épcca, era comandada por dois homens de vinculação partidária de grande destaque: João Francisco Lisboa, deputado liberal na Assembléia Provincial, e Francisco Sotero dos Reis, deputado situacionista. Os jornais mais importantes eram a Crônica Maranhense, orgão da oposição e o Investigador Maranhense, que defendia a politica oficial.

Tal campanha jornalística era secundada por uma dezena de pequenos jornais, destacando-se dentre eles o famoso Benteví de Estevão Rafael de Carvalho, que sempre pregara abertamente a revolução e dedicava-se a desmoralização sistemática de pessoas ligadas ao governo.

Discutia-se no Rio de Janeiro a Lei de interpretação do Ato Adicional, quando a Assembléia Provincial do Maranhão, antecipando-se às decisões do Senado, aprovou duas leis - a dos prefeitos e a das guardas-nacionais - inspiradas no espítito da pretendida interpretação. Essas duas leis modificaram a estrutura e a organização do poder municipal, que passou a depender diretamente do presidente. Este nomeava os prefeitos, que passavam a exercer a maioria das atribuições anteriormente conferidas aos juizes de paz que, tradicionalmente, vinham sendo eleitos pelas câmaras municipais e, portanto, representavam os interesses das famílias mais poderosas da região. A fim de aumentar o poder dos prefeitos a Assembléia, baseando-se no argumento de que a força cívica era

(1). - Crónica Maranherse n? 100, 10-1-1839, p. 405-406. 
"nula por todo o interior e na cidade mal organizada" (2),

confiou-lhes o encargo de organizar e chefiar a guarda-nacional por todo o interior da Província. Como consequência o poder policial ficou vinculado diretamente ao governo. Era a tendência centralisadora que emanava da Corte e rapidamente repercutia no Maranhão.

A gritaria dos liberais foi imediata. Consideraram inconstitucionais as medidas tomadas, valendo-se inclusive de opiniōes emitidas por jornais do Rio de Janeiro, como o Sete de Abril e o Despertador, que apesar de serem considerados "jornais ministerais", qualificaram a Assembléia do Maranhão como usurpadora e seus atos

\section{"desastrosos e atentatórios da integridade do Império e da uni- dade nacional" (3).}

Senhores absolutos do poder, os cabanos procuraram por todos os meios disponíveis punir os membros da oposição. Para tanto usaram o recrutamento indiscriminado para enfraquecer a posição dos fazendeiros bentevís do interior. De suas fazendas saiam boiadeiros, feitores, escravos e agregados para integrarem a guarda-nacional. Não respeitaram os dispositivos legais que impediam a convocação de homens casados e filhos-família, provocando assim a ira dos cidadãos até então intocáveis em seus privilégios. Uma análise superficial poderia levar a crer que esta atitude quebrava antigos privilégios estamentais, mas os cabanos pertencendo ao mesmo grupo social de seus inimigos apenas os enfraqueciam momentaneamente.

Neste clima de incompatibilidades, surgiu o manifesto de Raimundo Gomes, cuja responsabilidade os cabanos atribuiram aos liberais.

A imprensa situacionista, através da pena de Sotero Reis, viu nos ataques dos bentevís e principalmente nos do jornal Crônica Maranhense a preparação ideológica da revolta:

"Prove o Sr. Lisboa que Raimundo Gomes e seus sequazes năo empunharam as armas para sustentar as doutrinas da Crônica e do maligno Benteví, seu satélite" (4).

Estas invectivas tambem lançava o mesmo redator nas páginas do Investigador, fazendo com que João Lisboa respondesse:

(2). - Expressão de Sotero dos Reis redator do jornal situacionista o Investigador apud Crônica Maranhense, 31-1-38.

(3). - Crônica Maranhense no 106, 31-1-1839, p. 427.

(4). - A Revista n? 18. 
“ $O$ colega do Investigador é terrivel nas suas acusações! Ultimamente lembrou-se de dizer que a Crônica com todas as suas forças havia pregado a resistência a vários atos da assembléia provincial, e que dessas pregações nasceram as desordens da Manga! Lembramo-nos bem de ter analisado esses atos, mostrando sua incostitucionalidade, e os motivos torpes que os produziram; mas daí a pregar resistência, larga é a distância, e ainda o repetimos, nessa parte estamos mais do que justificados pelo ministerialismo da corte, em cuja opinião o contemporâneo não toca, nem que o esquarteje. Queira por quem é dizer-nos em que número da Crônica se acham essas provocaçōes? (...) O que ha aqui de ver é que na opinião do contemporâneo, Raimundo Gomes e seus sequazes se puseram em campo inflamados com a leitura dos jornais da oposição: eles que ainda a poucos dias não tinham capacidade para prođuzir as estrambólicas requisições que tem dirigido a várias autoridades e cidadãos!. O rompimento desse aventureiro devemo-lo às violências dos prefeitos, como à sua inépcia se deve o andar ele ha mais de mês e meio devassando impunemente o território da província. Com força e verdade disse o Sete de Setembro dele e dos seus: SÃO REBELDES MISERÁVEIS QUE ARMARAM CONTRA OS REBELDES PODEROSOS" (5).

Apesar de ter sido um dos mais clarividentes publicistas de sua época, João Lisboa não poude escapar à influência de famílias poderosas. Era o preço que o jornalismo político pagava por difundir idéias liberais num país escravocrata. Encontra-se nas relações de Lisboa com a família Franco de Sá, latifundiários poderosíssimos de Alcântara, um vínculo de dependência bastante expressivo. Chegou a defende-los em seu jornal por terem sido chamados de "opressores do povo" nos seguintes termos:

"... a influência dos senhores Sás é pelo menos manifesta; mas dessa se devem eles honrar, porque tem todos os títulos legítimos para exerce-la. Família numerosa, riqueza, talentos e alianças pelos laços de parentesco, amizade, e conformidade de idéias políticas, com outras famílias que se acham na mesma posiçăo, como sejam as dos Ribeiros, Costas Ferreiras, Costas Leites... Ora, todas estas famílias possuem em propriedade grande parte do território e tem por si as simpatias das classes inferiores, mais moralizadas por aqueles lugares, que em nenhum outro da província" (6).

(5). - Crônica Maranhense, 31-1-1839, n० 106, p. 429.

(6). - Carta a Joaquim Franco de Să, in Crônica Maranhense de 16-4$-1840, \mathrm{n}^{\circ} 229$, p. 917. 
Foi a esta classe de pessoas que João Lisboa identificou o partido liberal e a sua luta política; porque embora falasse em defesa do povo e dos oprimidos, na realidade estava defendendo os interesses das grandes famílias proprietárias, que como os Jansen Pereira tinham por si a "liderança natural que os seus bens the conferiam" e a "açăo moralizadora" que exerciam na sociedade.

Muito em breve, os poderosos latifundiários dispensariam a pena dos jornalistas, e formariam os quadros políticos quase que exclusivamente de pessoas saidas de seu próprio meio. Um exemplo deste comportamento foi dado pela própria família Jansen Pereira que projetou-se politicamente através da Balaiada, armando às suas expensas um batalhão da guarda-nacional, sob o comando de Isidoro Jansen Pereira. Um ano mais tarde, em 1840, já possuia um jornal o Guajajara e chefiava o mais importante grupo de oposição aos cabanos (7), controlando as listas de candidatos do partido liberal às eleiçōes, e alijando João Lisboa da liderança e da própria candidatura.

Enquanto os setores políticos enfrentavam-se acirradamente, Raimundo Gomes iniciava sua marcha pelo interior do Maranhão, arregimentando em torno de si elementos marginalizados pelo modo de produção latifundiário-escravocrata: desertores da guarda-nacional - vitímas do recrutamento violento e da disciplina feroz -, escravos fugidos, pequenos artesãos sem residência fixa, vaqueiros sem trabalho, assaltantes de estradas, agricultores espoliados de suas terras, sertanejos retirantes do Ceará, etc. .

Desde os inícios do movimento os bentevís estiveram implicados na evolução dos acontecimentos da Balaiada, quer pela conivência das autoridades, quer pelo fornecimento de suprimentos durante o tempo em que percorreram o sertão. Uma testemunha da luta reproduziu em seu depoimento a voz corrente da época:

"É constante que os vereadores da câmara, e o juiz de paz da Manga protegeram Raimundo Gomes" (8).

Esta afirmativa foi desmentida pela imprensa liberal, mas os fatos demonstraram que, embora poucos vaqueiros pudessem ter conseguido sucesso no assalto a uma cadeia, do interior, este acontecimento

(7). - Apud Jerônimo J. Viveiros de Castro, A rainha do Maranhão, Publicações do S. E. N. E. C., Maranhão, Departamento de Cultura dó Estado, 1965, p. 13.

(8). - J. M. Pereira de Alencastre, Notas Diárias sobre a revolta civil que teve lugar nas provincias do Maranhão, Piauy e Ceará, pelos anos de $1838,1839,1840,1841$, escritas em 1854 à vista de documentos officiaes. R. F. H. G. B. T. 35,1872 . 
por sí mesmo, não justificaria um manifesto de teor político. Analisando este manifesto, observa-se que ele contem duas ordens de reivindicações: as dos bentevís e as populares. Pode-se considerar os 3 primeiros artigos (referentes a obediência à Constituição; respeito às garantias individuais; demissão do Presidente e Vice-presidente da Província; aboliçãa dos cargos de Prefeitos, Sub-prefeitos e Comissários) de interesse exclusivo dos bentevís. Entretanto, Raimundo Gomes não se limitou apenas a transcrever opiniōes alheias. Revelava-se o lider que viria a se tornar, escrevendo o $4^{\circ}$ artigo no qual exigia a expulsão dos portugueses - simbolos populares da opressão do grupo social dominante -, e principalmente encerrando o manifesto com a expressão: "Fora feitores e escravos!"

Em janeiro de 1839, Manuel dos Anjos Ferreira, o Balaio, já se alistara no movimento, tendo o seu grupo se dirigido a Tutoia

"onde se demorou pouco mais de uma hora, sendo alí pelo juiz municipal Joaquim Antônio Gomes da Silva gratuitamente municiado com cinco paneiros de farinha; e ali obteve levar cento e tantos cartuchos e algumas granadeiras, d'onde saindo procurou a beira do rio Parahiba..." (9).

E claro que esta ajuda foi contestada pelos jornais liberais:

"Ocupemo-nos agora com as participaçóes dos prefeitos. 0 do Brejo não podia deixar de acusar o honrado juiz municipal de Tutoia, mas do que? de haver municiado gratuitamente a Raimundo Gomes com cinco paneiros de farinha! Queria acaso S. S. que o juiz municipal os vendesse a dinheiro contado? ignora acaso o bravo inimigo (...) que por toda parte por onde andou Raimundo Gomes extorquiu farinhas, bois, cavalos, armas e muniçōes que encontrava, $\mathrm{e}$ isto em forma de pedido? poderia alguem recusar, sem correr grande risco, o que fosse exigido por um malfeitor a testa de 100 homens?" (10).

Todas as expedições oficiais de repressão tinham sido até então, completamente ineficazes.

Em março de 1839 tomou posse da presidência do Maranhão Manuel Felizardo de Sousa e Melo, em substituição a Vicente de Camargo.

(9). - Carta de Severino Alves de Carvalho, Prefeito da Comarca do Brejo ao Coronel Joaquim José Gonçalves, Prefeito da Comarca do Itapicuru. 7-2-1839.

(10). - Crônica Maranhense, 22-2-1839, no 111, p. 449. 
Durante os primeiros meses de seu governo a situação política manteve-se inalteravel. No entanto, várias notícias divulgadas sobre o levante faziam crer que o seu fim estava próximo e que as forças oficiais haviam conseguido sufoca-lo. Rapidamente porem os acontecimentos desmentiram os prognósticos. O presidente enviou para combater os balaios uma expedição de 400 homens comandados por Pedro Alexandrino, que foi vencida pelas guerrilhas dos sertanejos. Um depoimento insuspeito no caso em questâo assinala:

"Como é facil de prever, depois desta vitória, fortificados os rebeldes pelo grosso da expedição que se lhes incorporou e, bem fornecida agora de armamento e munição, a sedição tomou aspecto assustador" (11).

Novos contingentes tambem chegaram-lhes com Lívio Lopes Castelo Branco e Silva, jornalista exaltado do Piauí, onde tinha a cabeça a prêmio. Trouxe consigo 600 homens e a intenção de expandir o movimento pelos Estados do Norte: Muitos atribuiram-lhe a idéia de atacar a rica cidade de Caxias, pois consideravam os demais chefes "muito ignorantes, para engendrarem tal plano".

Durante todo o período inicial da Balaiada, os bentevís não cansaram de responsabilizar os cabanos pelo crescimento da revolta, pela ineficiência da administração, pela corrupção da guarda-nacional e, aproveitando-se da insegurança geral, vaticinar um grande derramamento de sangue na Província. Pretenderam manipular os revoltosos, transformando-os em instrumentos de suas ambições através de habil campanha jornalística, na qual divulgavam vários manifestos dos chefes do movimento, veiculando as razões que os moviam, sem contudo hipotecar-lhes solidariedade. Os balaios passaram a te-los como aliados incondicionais, como atesta a volumosa correspondência que enviaram aos jornais de São Luís.

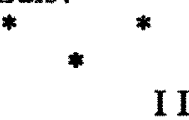

\section{PROCLAMAÇÃO.}

"Bravos Maranhenses.

A horda de salteadores, que hasteou o pendão do roubo, e assassinato no interior, prosegue desenfreiada, e ameaçadora na

(11). - Depoimento do Tenente Coronel Ricardo Leão Sabino - a Rodrigo Otavio de Langaard Menezes - A Balaiada, 1839. Depoimento de um dos heroes do cerco de Caxias sobre a revolução dos Balaios. RIHGB, 1903, T. LXV. 
carreira dos crimes que encetou; e á despeito das energicas providencias, que o Governo não tem cessado de dar, a rebellião achou novo theatro para os seus horriveis atentados: Caxias está em poder dos facciosos! Não desanimeis porem com este acontecimento inesperado; grandes recursos ainda nos restão, novos auxilios foram pedidos aos nossos irmãos do Norte, e Sul; todas as medidas estão tomadas para preservar a Capital, para sofocar a anarchia nos pontos que ela infesta. Dignos habitantes do Maranhão é pois chegado o momento de estender o patriotismo, que vos anima; vinde unir-vos em torno do vosso Presidente, e pressurosos acudi aos reclamos que vos dirigir para a defesa de vossas vidas, e propriedades, Cidadãos Brasileiros de quaesquer opiniões politicas, abdcai n'este solemne momento as rivalidades que vos retalhão, e unidos em um só interesse, conspirai todos para a salvação da Provincia. Eia valorosos Maranhenses depois de tantos sacrificios ainda alguns esforços, e a Legalidade vai triunfar:

Viva a Religião

A Integridade do Imperio

O Senhor D. Pedro $2^{\circ}$

E os bravos Maranhenses.

Palacio do Governo do Maranhão em 13 de Julho de 1839. Manoel Felisardo de Souza e Mello".

Com a tomada de Caxias, segunda cidade da Província, em julho de 1839, significativas mudanças operaram-se tanto no comportamento político dos grupos dominantes, como no desenvolvimento da ação revolucionária. Em São Luís, o temor de uma marcha "rebelde" sobre a capital generalizou-se. Ante a patética proclamação do presidente, os habitantes da cidade começaram a preparar-se para a resistência, e os liberais a procurarem uma saida para sua incômoda situação. João Lisboa empenhou-se em reunir partidários da "oposição constitucional" em torno do presidente - que passou a considerar apartidário - , pelo menos naquele momento crítico. Separando o partido cabano - que continuavam a atacar violentamente, responsabilizando-o pelos desmandos na Província - da política pessoal do presidente, os liberais demonstraram toda a sua fraqueza ideológica e claramente revelaram a exploração que vinham fazendo da luta do Balaio em proveito próprio.

Até então, os liberais (bentevís) confundiam-se em várias posições frente ao movimento. Os da capital procuravam através dele conseguir sucesso nas eleições que se aproximavam e novamente controlar o governo. No interior a situação foi muito mais complexa. Alguns uniram-se francamente à revolução a fim de impetrar vinganças pessoais; outros, muito mais numerosos, colocaram-se na situação de ví- 
timas constrangidas a colaborar, esperando que os acontecimentos futuros os beneficiassem. Encontram-se tambem em documentos revolucionários, assinaturas, de bentevís que aderiram incondicionalmente aos balaios, sem pertencerem ao quadro da situação política anterior (12).

A Balaiada já atingira o Piauí. Crescera o número de seus contingentes, alastrando-se de tal forma que já assumia coloração locais. Seus participantes nẫo compunham um grupo homogêneo, assim como os seus líderes. Em todos os manifestos por eles redigidos declaravam-se bentevis, defensores da religião, da Constituição, fiéis a D. Pedro II, contrários ao despotismo e à lei dos prefeitos, e principalmente inimigos dos portugueses. Todavia esta uniformidade nos pronunciamentos pouco signíficava. A verdadeira história da Balaiada estava nas entrelinhas dos depoimentos mal redigidos, na origem social de seus participantes, no número de seus mortos e na anistia oferecida a muitos, mas só beneficiando poucos.

Para melhor compreensão da revolução pode-se estabelecer uma distinção entre balaios e bentevís. Os balaios homens do sertão e marginalizados em geral, alinhavam-se em torno de Raimundo Gomes, Manuel Francisco dos Anjos Ferreira, D. Cosme Bento das Chagas, Milhone, Mulungueta, Coque, João da Matta Castelo Branco, o índio Sebastião José de Matos, João Julião, Relâmpago, Trovão, Corisco, Raio, Canino, Sete Estrelas, Tetéu, Andorinha, Tigre, João Cardoso, Gitirana, Ruivo etc. Os bentevís - oriundos, em sua maior parte, da população das vilas e povoados, incluiam oficiais e soldados da guarda-nacional, políticos do Ceará e Piauí, membros do partido liberal, juizes de paz, etc. - , aglutinavam-se sob a liderança de Lívio Lopes Castelo Branco e Silva, Pedro de Moura Albuquerque, Tenente-Coronel Sebastião José de Aguiar, Capitão Manuel Lucas de Aguiar, Alferes José Felix de Aguiar, Capitão Francisco Tavares de Lira, Major Conrado José da Costa, Tenente Francisco Xavier da Fonseca, etc. . Esta distinção entre balaios e bentevís tem como principal fundamento tanto os motivos que levaram os indivíduos a engajarem-se na luta, quanto sua origem social, embora não pretenda estabelecer limites rigorosos. Os balaios foram vistos por seus contemporâneos como pertencentes às "classes inferiores", sem princípios, "assassinos ferozes", ladrões e cultivadores de toda sorte de vícios. Outro aspecto

(12) . - E o caso do poeta Pedro de Alcântara Soares. Redigiu uma proclamação $\mathrm{cm}$ nome dos chefes rebeldes de Paranaguá, de estilo totalmente diverso dos demais: 'Habitantes de Paranaguá, meus patrícios! A orgulhosa sanha sugerida do centro do Palácio de Oeiras como as fumegantes fornalhas, digo, fumegantes labaredas das incendiadas fornalhas da Babilonia, é que tem promovido a desgiaça d'esta província e os males que nos tem sobrevindo, etc." apud J. M. Percita de Alencastre, op. cit., p. 476. 
bastante evidenciado em relatórios dos expedicionários legais foi o fato de serem homens de cor: "índios, negros, mestiços de toda espécie". De relatórios oficiais são os seguintes trechos:

"mandei chamar o principal dos índios de São Miguel, Sebastião José de Matos; fiz-lhe conhecer as vantagens que da obediência ao governo resultam a todos, mostrando-se convencido queixou-se de violências praticadas e da queima de nove casas de índios" (13);

num ofício do Cel. Coqueiro le-se:

"Foi aí que aparecen o Cosme. Evadido das cadeias da capital tido e havido por feticeiro e gozando por isso de grande ascendência entre os de sua raça, pôs-se este famigerado bandido à testa de três mil escravos sublevados, trazendo por esta forma novo e inesperado concurso para a rebelião" (14).

Em vários documentos, oficiais ou não, encontram-se sempre referências à coloração da pele dos revolucionários, demonstrando isso o preconceito que existia na sociedade maranhense, onde as famílias aristocráticas procuravam esconder toda e qualquer ligação consanguínea com pessoas que não fossem brancas. Assim qualificavam os revoltosos:

"Na Manga um preto de nome José Gonçalves cometera um assassinato. Raimundo Gomes, irmão de José Gonçalves e destemido facínora, vendo o irmão e companheiro de tropelias preso e recolhido à cadeia do lugar, foi ter com o Juiz de Paz e pediu-lhe que proporcionasse a fuga do criminoso" (15);

um outro depoimento afirmava

"... um mulato por nome Manuel Francisco que se diz Tenente dos pretos é o que tem mais seduzido à gente de cor porque esta gente muito acredita em seu semelhante" (16).

(13). - Ofício do Tenente Coronel Comandante das forças expedicionárias ao presidente Manuel Felizardo - apud Astolfo Serra, A Balaiada, Biblioteca Militar, Rio de Janeiro, Bandeshi, p. 137.

(14). - Apud Astolfo Serra, op. cit., p. 137.

(15). - In Depoimento de Ricardo Leão Sabino, op. cit., p. 292.

(16). - Ibidem. 
Da mesma forma que empregavam para os balaios termos como: o preto Antônio, o cafuz João, o mestiço Francisco, o caboclo Coque, ressaltavam tambem serem eles de origem humilde e desconhecida, aliada à perversidade sem limites própria dos sertanejos. Eram os preconceitos de "casta", os estereótipos seculares com os quais a aristocracia se protegia do contacto com os pobres. Os próprios bentevís, que municiavam os balaios, referiam-se a eles como a servidores inferiores.

Ribeiro do Amaral, no seu trabalho Apontamentos para a História da Revolução da Balaiada na Província do Maranhão, representa muito bem na historiografia o pensamento do grupo dominante ao se referir aos balaios com expressões como:

"massas indisciplinadas, apanhadas aqui e ali da mais baixa ralé da sociedade", dominadas pelo "desenfreamento, avidez de pilhagens das classes inferiores" (17).

Quanto às barbaridades cometidas durante a revolução, é interessante notar-se que foram atribuidas exclusivamente aos balaios, e nunca aos bentevís, ou seja aos liberais.

Há sem sombra de dúvidas duas histórias da Balaiada; uma dos sertanejos, outra das lutas entre cabanos e bentevís. Aparecem de tal forma mescladas que é impossivel explicar uma sem a outra. No Piauí, onde o movimento se alastrou dias após a tomada de Caxias, os ataques eram endereçados ao barão de Parnaiba, déspota desumano que, nem mesmo as versões históricas oficiais desmentem os crimes que praticou (18). Através dos termos de uma capitulação proposta pelo chefe da revolta em Paranaguá, pode-se aferir o estado da região. Deste documento deprende-se a insatisfação reinante motivada pela participação de estrangeiros no governo, pelo desrespeito às decisões das Câmaras municipais, pelo arbítrio dos prefeitos, pelas cabalas eleitorais, pela ausência de informações sobre o destino das rendas públicas, pela existência de guardas privadas concedidas pelo próprio pre-

(17) . J Ribeiro do Amaral, Apontamentos para a História da Revolução da Balaiada na Província do Maranhão. Maranhão, Tip. Teixeira, 1898$-1906,3$ vol.

(18). - "Ninguem pode contestar que grandes barbaridades se perpetraram contra os rebeldes do Piauí horrores e sobre horrores n'essa luta fraticida se encontram a cada passo. Ordens reservadas mandavam que se fizessem espingardamentos em massa, sob pretexto de não haverem prisões para tantos prisioneiros! As expressões de que usava o honrado barão em suas ordens secretas de extermínio, eram as seguintes: - sejam estoporados esses tratantes não tenho onde guarda-los". Apud Pereira de Alencastre, op cit., p. 472. 
sidente da Província (19). Pereira de Alencastre, que se refere aos balaios em março de 1839 como

"imensos grupos, que em todas as direções percorrem desordenados, saciando seus instintos ferozes no assassinato e no roubo",

não usa as mesmas expressões para os rebeldes do Piauí, aos quais justificou no seguinte texto.

"Não é simplesmente a febre revolucionária que se apodera dos espíritos dos habitantes do Piauí: a fatal e insólita administração do barão da Parnaiba trazia a província de há muitos anos debaixo da mais horrivel opressão. O momento era o mais azado para uma manifestação: era infalivel o seu aparecimento como um protesto solene contra as iniquidades de uma ditadura selvagem (...) Justiça seja feita a muito desses, que no Piauí foram encontrados na luta empunhando as armas da rebelião: eles não queriam o assassinato e o roubo, desejavam entrar na posse de uma herança sagrada - a Constituição - que com tanta iniquidade lhes era sequestrada!" (20).

Negaram-se todos a compreender os motivos dos sertanejos, negros aquilombados e vaqueiros aos quais a Constituição, pela qual empenhavam-se na defesa em seus manifestos, nada traria de positivo benefício.

Em suas proclamações, serviam-se os balaios da mesma linguagem utilizada pela ideologia dominante, introduzindo as vezes algumas inovações que, embora poucas e curtas, expressam profundo sentido social. O manifesto de João da Mata Castelo-Branco, que intitulava-se chefe das forças "bentevís" do Piauí, dizia:

"Eu saúdo a todos os brasileiros pobres, que forem amantes de sua pátria e de nosso Imperador. Meus irmãos agora é ocasião de dos brasileiros mostrarem a sua firmeza e amor à pátria; pois me acho nesta província em defeza do partido Benteví, que defende a santa religião católica romana, a coroa de nosso Imperador Pedro II, a constituição, nossa pátria, nossas famílias, e a nós mesmos da escravidão dos Cabanos; pois esses malvados cabanos querem nos por no cativeiro. (...) e os, que não puderem

(19) - Artigos de uma capitulação proposta pelo chefe da revolta do Paranaguá, Manoel Lucas de Aguir ao comandante da coluna do Oeste, José Martins de Sousa (4-3-1840) apud Pereira de Alencastre, op. cit., p. 477.

(20). - Idem, ibidem, p. 429. 
vir por qualquer situação de molestia, escreva-nos, e nos supra com pólvora e armas, porque assim dão provas de Benteviz e os que não vierem ficarāo tidos como cabanos. Venham meus irmãos, não sejam ingratos aos patrícios e irmãos pobres. Corumbá em 3 de abril de 1840" (21).

Percebe-se claramente que a luta já tinha assumido um carater bem diferente do pretendido pelos liberais bentevís. Para o chefe balaio a luta era entre pobres, que para ele eram identificados aos bentevís, e ricos ou cabanos.

De há muito o vocábulo benteví vinha assumindo conotações diferentes, passando desapercebido a muitos o divórcio que se estabelecia entre a revolução e a agitação política. Quando do prolongado cerco e da ocupação de Caxias, Raimundo Gomes escreveu expressiva carta a João Francisco Lisboa que merece ser transcrita:

"Desde maio, que tenho escrito a V. S. várias cartas e de nenhuma tenho tido resposta: não sei a que atribuir este tão rigoroso silêncio de sua parte; continuo a faze-lo para desperta-lo do letargo em que parece está comigo. Vi a que dirigiu ao Silveira, "e não sei qual o motivo de nada me dizer a mim", devendo estar certo da minha boa fé e partiotismo e do quanto tenho feito a prol do partido que seguimos e dos meus desejos para que tudo vá em boa ordem. A minha ida a Caxias foi a mais necessária, atento as malversações de alguns homens estorrados, e que presumem que o patriotismo e a liberdade brasileira, consiste em matar e roubar: com efeito com a minha presença serenaram os ânimos, evitei o massacre e o saque e se não fiz tudo quanto pedia a honra da nossa causa, confesso-lhe que não tive quem me ajudasse: finalmente, a enumerar-lhe os incômodos e aflições que tive para deixar Caxias em sossego, como ficou, seria um nunca acabar, e deixo isso àqueles que o presenciaram. (...) Como mandei de Caxias uma comissão de brasileiros que o conselho julgou dignos de representarem perante o presidente da província nossas requisiçōes, $\mathrm{e}$ até hoje ainda nada disseram a respeito do que se thes incumbiu ... pois tendo eu oito mil homens em armas, não posso estar parado, nem conte-los uma vez que haja demora em tal resposta; por isso que tambem lhe rogo a brevidade da vinda da deputaçäo, e por ela espero que V.S. e mesmo o mais breve possivel me diga alguma coisa, dando-me seus conselhos para saber o que hei de obrar a respeito. Desejo-lhe saude, e sou da

(21). - Idem, ibidem, p. 429. 
V. S. Amigo P. obrigado e criado. Raimundo Gomes Vieira. Jutai Coroaté, 31 de agosto de 1839" (22).

Esta carta suscitou nova polêmica entre os políticos de São Luis . A fim de dirimir quaisquer dúvidas sobre a sua correspondência com Raimundo Gomes, João Lisboa afirmou que o fato do bandido considera-lo seu correligionário, devia-se à sua ignorância e incapacidade de distinguir as enormes diferenças que os separavam.

Lida com atenção a missiva de Raimundo Gomes, não é absolutamente um pedido de interseção. Há nitidamente em suas palavras, um sentido diverso daquele que foi atribuido por seus contemporâneos, pelo menos em seus artigos de jornal. Maliciosamente atribui toda a responsabilidade da tomada de Caxias aos seus habitantes, demonstra embora contraditoriamente a existência de uma correspondência regular com João Lisboa, e finalmente numa única linha ameaça o governo com seus 8.000 homens em armas, concluindo numa manha bem cabocla, pedindo conselhos. Sabe-se que não era os de João Lisboa que necessitava. Era o vencedor e não o vencido, soube com sua carta aumentar o pânico de toda a população da capital. Era chegado o momento dos balaios começarem sua própria revolução. Homens duros, habituados ao sofrimento, à violência e ao sangue, nada mais esperavam de pusilânimes políticos. Inúmeras cartas escreveram os balaios, sempre levantando suspeitas sobre os destinatários, blasonando o elevado número de armas que possuiam. Como não atribuir nesse momento a elas um planejamento consciente de aumentar o clima de insegurança, ainda mais quando sabemos que

\footnotetext{
"as armas que dispunham, na maior parte espingardas de caça e chuços, não lhes favorecia a funesta empresa"? (23).
}

No livro de Astolfo Serra há colocações bastantes discutíveis sobre as relações de João Lisboa com a Balaiada, como se pode constatar no seguinte trecho:

"O que é fora de dúvida é que João Lisboa não tomou parte na revolução. Não conspirou. Indiretamente, a sua atuação foi de verdadeiro apóstolo da rebeldia. Os seus artigos produziram na massa o espírito de rebeldia. Não deixa pois, de ser um dos agentes intelectuais da Balaiada. Daí a ser porem, um cúmplice, vai muito espaço" (24).

\footnotetext{
(22). - In Crônica Maranhense, n० 173, 3-10-1839, p. 696.

(23) . - Depoimento de Leão Sabino, oficial em chefe da defesa de Caxias, op . cit.. p. 298.

(24). - Op. cit., p. 247.
} 
Baseando-se ainda em um trabalho de Carlota de Carvalho, o historiador afirma que o jornalista

\footnotetext{
"lutava, mas não se unia à massa; combatia pelo povo, mas seria incapaz de fazer parte de qualquer revolta com o povo".
}

Isto é tão claro que, apenas eclodida a revolta, quando o movimento se alastra e domina grandes áreas do sertão maranhense, ele, o mais autorizado chefe dos bentevís, a repudia de público:

"A oposição constitucional, de cuja opinião nos honramos em ser orgão adota por seus amigos, na crise atual, todos que empunharam armas em favor das instituições ameaçadas" (25).

Uma série de objeções podem ser feitas a estes juizos. Primeiramente, eles possuem contradições internas como a de afirmar que João Lisboa não conspirou para depois responsabiliza-lo por não assumir a direção de um movimento surgido sem o seu apôio. Outra incongruência acha-se ao mostra-lo como "apóstolo da rebeldia", mas sem ligações com a massa. Pode-se objetar que, se assim ocorreu, o apóstolo não escolheu bem os seus sectários, ou estes a aquele. Os objetivos dos bentevís foram em parte conseguidos no governo de Manuel Felizardo. Pressionado pelo fragor da luta e da ameaça que pairava sobre a Província, o presidente aproximou-se dos liberais da capital, prometendo-lhes em troca de uma ação medianeira a revogação da "lei dos prefeitos" e a "das guardas-nacionais". Era o primeiro sucesso dos liberais depois da queda de Feijó. Esta vitória thes bastava, pois era a que pretendiam. O prestígio dos cabanos estava abalado, era o momento de desvencilharem-se dos balaios.

Depois de haver incrementado a agitação revolucionária, o partido liberal, assustado com o desenrolar da luta, e ameaçado de perder suas propriedades e a situação que gozava, retirou todo o apôio ao movimento. Compôs-se com o governo, num acordo do qual os balaios ficaram de fora. O preço para que os liberais readiquirissem alguns cargos públicos foi altíssimo: a vida dos balaios. A aproximação dos liberais com o governo deu-se em três momentos distintos. No primeiro, proclamaram-se membros da oposição constitucional; no segundo tentaram negociar a paz com os balaios e no terceiro concitaram os bentevís a deporem armas e abandonar a luta.

A Crônica Maranhense e o Investigador são fontes históricas importantes para o esclarecimento da maneira como foi negociada a paz.

(25). - Op. cit., p. 247. 
Organizaram-se listas de contribuições com a finalidade de subornar alguns líderes e provocar a dissenção. Lançava-se mão da corrupção para enfraquecer a luta popular.

o Investigador teve notícias de que um grupo de comerciantes procurou o redator da Crônica a fim de propor-lhe que intercedesse junto ao governo pela abolição da "lei dos prefeitos", e em troca, lhe dariam 40 contos de réis para entrar em negociações com os balaios. Lastimava a baixeza e o terror dos negociantes e encontrava na atitude deles motivos para acreditar que João Lisboa era plenipotenciário dos rebeldes (26). A Crônica respondeu sem desmentir as informações, apenas afirmando que se o redator foi procurado era porque os chefes cabanos estavam desmoralizados e que o presidente da Província poderia fornecer todos os detalhes do acontecimento por estar bem a par deles. Ele, redator, havia se negado a recolher os fundos ou a organizar listas de contribuições, o mesmo porem não poderia dizer de Sótero dos Reis que

"Em presença do exmo. presidente da província, afirmou que ao partido dominante não só convinha abolir-se a lei dos prefeitos e da guarda nacional, porem faria ainda, outras concessões importantes, uma vez que a oposição votasse por certas medidas, sendo uma delas a concessão de 80 contos para despezas secretas! ... é forçoso convir que seriam destinados a corromper os rebeldes, a menos que se não queira temerariamente supor que era esse o preço porque o colega avaliava as suas duas leis, e que seria repartido entre os amigos a título de indenização dos prejuízos resultantes da prometida abolição" (27).

Um dos primeiros balaios a trair o movimento foi Coque. Cedeu aos "argumentos" dos políticos, mas estes não contentes apenas com a deserção passaram a explora-la. Foi divulgado pela imprensa que Coque possuia uma correspondência altamente comprometedora de cidadãos eminentes na província e no partido liberal. Os jornais cabanos passaram a elogiar a conduta de Coque que assim se justificava:

"tinha estado iludido que ia prestar serviços à pátria".

Afirmava ainda que soubera conter na inação o bando que chefiara em Croatá, e que apesar de serem as suas forças consideráveis, viera apresentar-se cheio de fé e contrição à legalidade. Os mesmos

(26). - Investigador Maranhense, São Luis, Tip. Constitucional. Red. Francisco de Salles Nunes Cascaes, Sótero dos Reis e outros,n 96.

(27). - Crônica Maranhense, $\mathrm{n}^{\circ} 175,10-10-1839$, p. 703-4. 
homens que discutiam no gabinete da presidência uma forma de corromper o inimigo, os mesmos que escreviam cartas secretas para o interior da província, agora exigiam, alem da humilhação e da traição, a colaboração nas intrigas da classe dirigente. Coque legalista era mais util do que nunca. A Crônica o anatematizou:

"Um salteador que acaba de por fogo e sangue a melhor da província, que tomou uma parte ativa na destruição da opulenta Caxias, de que foi um dos primeiros cercadores, que dali desceu carregado de despojos a assentar o novo arraial de bandoleiros no Croatá ... ; esse miseravel, coberto de crimes, ... esse homem, assoprado por pretendidos legalistas, que não tem aos rebeldes a quarta parte do ódio que consagram aos seus adversários políticos, arroja-se a escrever para jornais, alardeia os seus serviços, humanidade, patriotismo e boa fé, liberalisa insultos e ameaças a cidadãos honestos que nunca manejaram a faca do assassinato, o machado do arrombamento, e o facho do incêndio!" (28).

\section{I 1}

"Proclamação. - Maranhenses! Nomeado presidente e comandante das armas desta província, por carta imperial de 12 de dezembro de 1839, eu venho partilhar das vossas fadigas, e concorrer, quanto em mim couber, para a inteira e completa pacificação desta bela parte do Império.

Um punhado de facciosos, ávidos de pilhagem, poude encher de consternação, de luto e de sangue, vossas cidades e vilas! $O$ terror que necessariamente deviam infundir-vos esses bandidos, concorreu para que se engrossassem suas hordas; contudo graças à providência e às vitórias até hoje alcançadas pelos nossos bravos, seu número começa a diminuir diante das nossas armas. Mais um esforço e a desejada paz virá curar os males da guerra civil.

Qualquer que seja o estado em que se acham hoje os rebeldes, eu espero com os socorros que o governo geral vos envia, e com a força que me acompanha, fortificar nossas fileiras, e não abandonar-vos enquanto não os houver debelado. Eu passo a fazer os melhoramentos que julgo necessário ao nosso exército, e com a maior brevidade possivel me colocarei à sua frente. Maranhenses!

(28). - Crônica Maranhense, n॰ 196, 19-12-1839, p. 787. 
mais militar que político, eu quero até ignorar os nomes dos partidos que por desgraça entre vós existam. Deveis conhecer a necessidade e as vantagens da paz, condição da riqueza e da prosperidade dos povos; e confiando na divina providência, que por tantas vezes nos tem salvado, espero achar em vós tudo o que fôr mistér para triúnfo da nossa santa causa. -

Palácio da Presidência na cidade de São Luiz do Maranhão, 7 de fevereiro de 1840 .

Luiz Alves de Lima".

Decidiu-se no Rio de Janeiro, que para por fim à luta do Maranhão, dever-se-ia nomear um outro presidente que enfeixasse em suas mãos tanto o poder civil quanto o militar. A Carta Imperial de 12 de dezembro de 1839, nomeava o Cel. Luiz Alves de Lima, para o posto de presidente comandante das armas do Maranhão,

"com poderes para entrar no Piauí e Ceará, ficando sob suas ordens todas as forças que nessas províncias operavam" (29). 1840 .

O novo presidente chegou no Maranhão a 4 de fevereiro de

Os jornais entusiasmaram-se com o pronunciamento do presidente principalmente no que se referia aos partidos. Consideraram-no como um ato de independência política por parte de quem não queria servir de instrumento das facções. A província estava econômica e financeiramente arruinada. Comerciantes e fazendeiros uniam-se em listas de cidadãos que hipotecavam solidariedade ao governo. Proprietários de escravos que abandonando as fazendas, uniram-se a D. Cosme. O assassinato de feitores era comum, tendo a revolução já assumido a conotação de uma luta social sem precedentes.

A situação das tropas oficiais era calamitosa. Encontravam-se sem víveres, roupas e armamentos. De há muito não recebiam o soldo que o governo thes devia. Por estas razões atacavam a população sem mais se servirem de protocolares "requisições de guerra". Não encontravam mais boa vontade por parte de ninguem. Vários relatórios de oficiais atestam esta ausência de infra-estrutura dos expedicionários. Luis Alves de Lima começou por tomar medidas a esse respeito. Autorizou o pagamento dos soldos atrasados com a receita que trouxera

(29). - Apud Astolfo Serra, Caxias e o seu governo civil na Província do Maranhão, Rio de Janeiro, 1943, Biblioteca Militar, vol. LXVIII, p. 44. 
do Rio de Janeiro (30), coibiu os excessos contra a propriedade e a população civil (31), e exigiu rigorosa prestação de contas das despesas com víveres (32). Estas e outras medidas, como o pedido de tropas a Pernambuco e mais recursos financeiros, vieram organizar as forças oficiais quando os revolucionários já se encontravam nos limites finais de sua resistência. Abandonados pelos bentevís, enfraquecidos por deserções, os chefes começaram a se desentender. Batidos alguns grupos de Lívio Castelo Branco, este abandonou a luta. Escondido ficaria até o momento da anistia e beneficiando-se de sua influência ainda viria ocupar lugar de destaque na política e no jornalismo do Império. Sua luta foi apenas ocasionalmente a dos balaios, ele era um homem de posição social para quem houve perdão, e a quem se reconheceu apenas um equívoco em suas posições patrióticas. Talvez tivesse sido enganado pelos balaios e pela "lábia de Raimundo Gomes"...

Luis Alves de Lima dividiu a sua tropa de 8.000 homens em três colunas. A primeira operou na região entre Caxias e Pastos-Bons, a segunda entre Vargem-Grande e Brejo, e a terceira na zona de Icatú e Miritiba. Dever-se-ia fechar o cerco sobre Brejo que era o reduto dos balaios. Do Piauí tambem vieram contingentes militares. Derrotas em cima de derrotas obrigaram Raimundo Gomes a se retirar para o Piauí, onde ainda tentou reorganizar suas forças, mas foi vencido nas matas do Egito e Cumatá pelo Cel. José Cid

\section{"fazendo 1.091 prisioneiros, entre homens, mulheres e crian- ças" (33).}

Raimundo Gomes ainda conseguiu arregimentar 1.000 homens (34) e voltou ao Maranhão, mas foi sempre vencido e as forças debandadas cairam nas emboscadas dos grupos militares. $O$ final da luta foi extremamente doloroso, acompanhado pela fome e pela doença. Raimundo Gomes pediu condições para a capitulação, mas estas lhe foram negadas. Refugiou-se junto aos negros de D. Cosme, mas foi feito prisioneiro por eles. Os demais chefes da Balaiada estavam

(30) . - Ofício do Presidente do Maranhão, datado de 11 de fevereiro de 1840 ao Sr. Inspetor da Tesouraria, apud Crốnica Maranhense, n $216-$ 27-2-1840.

(31). - Ordem do dia $\mathrm{n}^{\circ} 9$ - Quartel da Presidência e do Comando das Armas. 24 de fevereiro de 1840, Apud Crônica Maranhense, 27-2-1840, $n^{9} 216$.

(32) . - Ordem do dia n' 10 - Quartel da Presidência e do Comando das Armas 24 de fevereiro de 1840. Apud Crônica Maranhense, 3-3-40, $\mathrm{n}^{\circ} 217$.

(33). - In Mario M. Meireles, História do Maranhäo. D. A. S. P. Serviço de Documentação, $1960, p, 266$.

(34). - Idem, ibidem, p. 266. 
mortos ou prisioneiros tendo D. Cosme, o "Tutor das Liberdades Bem-te-vis" ficado como principal comandante do movimento.

Com a maioridade do Imperador, pretendeu-se no Rio de Janeiro pacificar definitivamente o país. A 22 de agosto de 1840 foj promulgado um decreto de anistia a todos aqueles que por qualquer forma se tinham envolvido em crimes políticos até aquela data. $O$ seu § 1 dizia:

"Aqueles que seguem a rebelião nas províncias em que ela existe, deveräo para o fim de gozar da anistia concedida apresentar-se perante qualquer autoridade legal da mesma ou de outra província, no prazo de sessenta dias, contados da publicação deste decreto, na província que estiverem. São autoridades legais para este fím, näo só as civis das cidades, vilas e distritos, mas tambem as militares encarregadas de comando de exército, corpo ou posiçăo militar de legalidade" (35).

O benefício da anístia não abrangeu a maioria. Temiam os balaios entregarem-se às forças oficiais, pois quando Francisco Pedrosa rendeu-se com 1.700 balaios foi obrigado a combater D. Cosme para provar o seu arrependimento. Mario Meireles afirma:

"E, então, que Francisco Pedrosa, que ainda estava em Belágua, à frente de 1.700 balaios, pede condições de paz, e Caxias exige, preliminarmente, que combata os negros, como demonstração de seus reais propósitos” (36).

Os últimos bandos internam-se pelo sertão, alguns depõem suas armas como Pio, Tempestade, e Coco. Raimundo Gomes liberta-se de Cosme e ainda tenta apoderar-se do Rosário e Miritiba, mas sem nenhum sucesso. Não se sabe ao certo se foi aprisionado ou entregou-se. Foi exilado para São Paulo, morrendo de ferimentos ou assassinado na viagem.

D. Cosme ficou só. Não tinha motivos para entregar-se. Suas tropas lutavam sem nenhuma esperança, eram escravos, não queriam voltar ao jugo de seus senhores, pois tinham sido homens livres e temidos. Lutaram até a morte. D. Cosme foi enforcado. Acabava a Balaiada.

(35). - Decreto de anístia Geral, por ordem de S. M. I., 22-8-1840, rubricado por $D$. Pedro II e assinado por Antônio Paulino Limpo de Abreu, Ministro e Secretário de Estado dos Negócios da Justiça.

(36). - Mario Meireles, op. cit., p. 267. 


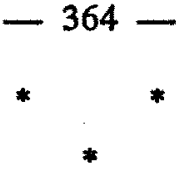

I V

Excertos do Relatório de Luis Alves de Lima ao deixar o Governo do Maranhão.

"Não existe hoje um só grupo de rebeldes armados, todos os chefes foram mortos, presos ou enviados para fora da província...

Se calcularmos em mil os seus mortos pela guerra, fome e peste, sendo o número dos capturados e apresentados durante o meu governo passante de quatro mil, e para mais de três mil os que reduzidos à fome e cercados foram obrigados a depor as armas depois da publicação do decreto de anistia, temos pelo menos oito mil rebeldes; se a estes adicionarmos três mil negros aquilombados sob a direção do infame Cosme os quais só de rapina viviam, assolando e despovoando as fazendas, temos onze mil bandidos, que com as nossas tropas lutaram, e dos quais houvemos completa vitória. Este cálculo é para menos e não para mais: toda esta província o sabe.

... A comarca do Brejo é a que mais contem em suas matas grande cópia de ociosos, e com menos de quinhentas praças não se fará a sua polícia...

De tudo que hei dito achará V. Excia. documentos na secretaria do governo, e na memória recente de todos, e termino desejando que V. Excia, neles encontre o mesmo acolhimento que me prodigalizaram... Deus Guarde V. Excia. - S. Luiz do Maranhão, 13 de maio de 1841. Luis Alves de Lima" (37).

Os partidos que viveram durante anos em torno das questões levantadas pela revolta desarticularam-se com o seu final. As antigas lideranças foram substituidas, mediocrizando-se o nivel de suas aspirações. Indubitavelmente o longo período de crise política favoreceu a divulgação e o desenvolvimento dos princípios ideológicos "liberais". Mesclados às mais reles polêmicas políticas, os anseios "liberais da classe dirigente" foram magistralmente expostos, oferecendo uma nítida visão da concepção de liberalismo que se tinha na época. Do poderoso partido cabano pouco restava, assim como os antigos "exaltados" retraiam-se amedrontados com as repercussóes da repressão. Depois de envolverem-se em demasia com a revolução, foram destrui-

(37). - Apud Astolfo Serra, Caxias e o seu governo... op. cit., p. 143. 
dos por ela própria. Os partidos continuaram a existir, mas como sombras do que foram. Famílias latifundiárias assumiram a liderança que sempre lhes coubera afastando os "teóricos" do partido. As questiúnculas substituiram definitivamente as questões de princípios, tudo voltava ao seu lugar. Os partidos mudaram seus nomes; denominaram-se Guajajaras (liberais) e Gaviões (cabanos). Dissidentes liberais uniram-se a dissidentes cabanos, antigos inimigos congratularam-se no novo consórcio eleitoreiro.

A população marginalizada que havia lutado durante dois anos, enfrentava dificuldades em ser reabsorvida pelo sistema de produção maranhense, assolado por uma de suas maiores crises. No próprio relatório do presidente há referências ao grande número de "ociosos" espalhados pelo sertão. O problema social continuava sem solução, mas bem mais agravado que anteriormente. $\mathrm{O}$ aparato ideológico que havia sido utilizado durante a revolução mostrara sua absoluta inconsistência. Os "ociosos" caçados no Maranhão desceram para os estados do Nordeste e engrossaram o contigente humano que viu no cangaço uma solução de sobrevivência.

MARIA DE LOURDES MONACO JANOTTI. - Nasceu em São Paulo, a 11 de fevereiro de 1938. Licenciou-se em História pela Faculdade de Filosofia, Ciências e Letras da Universidade de São Paulo (1959); doutorou-se em História na mesma Faculdade em 1971. Leciona no Departamento de História da Universidade de São Paulo desde 1965. Ministrou cursos na Disciplina de Metodologia e Teoria da História e atualmente dedica-se ao ensino de História do Brasil.

É autora dos seguintes trabalhos: João Francisco Lisboa: contribuição para o estudo da Historiografia Brasileira, (Tese de doutoramento) São Paulo, 1971 (no prelo, Ed. Ática); A Metodologia da História e seus problemas pedagógicos, in "Anais do V Simpósio Nacional dos Professores Universitários de História", Campinas, 1971; Um seminário sobre a peça teatral "Um inimigo do povo" de Henrik Ibsen, in "Revista de História", vol. XXXIV, n" 69, 1967; Comentário do livro de Pasquale D'Elia, Il lontano confino e la tragica morte del $P$. João de Moura $S$. I. missionario in Cina (1681-1726), in "Revista de História", vol. XXXI, n 62, 1965. 